\title{
ПРИНЦИПИ ПОБУДОВИ СИСТЕМ МОНІТОРИНГУ В ТЕПЛОЕНЕРГЕТИЦІ
}

\author{
Бабак В.П., член-кореспондент НАН України, Красильніков О.І., канд. фіз.-мат. наук
}

Інститут технічної теплофізики НАН Украӥни, вул. Желябова, 2а, Київ, 03680, Україна

Сформульовано базові принципи моніторингу об'єктів теплоенергетики, систематизовано основні види та завдання систем моніторингу теплоенергетичного устаткування, наведено загальну характеристику основних блоків апаратно-програмних засобів систем моніторингу, визначені перспективні напрями створення систем моніторингу в теплоенергетиці.

\begin{abstract}
Сформулированы базовые принципы мониторинга объектов теплоэнергетики, систематизированы основные виды и задачи систем мониторинга теплоэнергетического оборудования, дана общая характеристика основных блоков аппаратно-программных средств систем мониторинга, определены перспективные направления создания систем мониторинга в теплоэнергетике.
\end{abstract}

Formulated the basic principles of monitoring of the heat-power engineering objects; systematized the main types and tasks of monitoring systems of heat-power engineering equipment; general characteristic of the main blocks of hardware and software of monitoring systems is given; defined the perspective directions of creating monitoring systems in heat-power engineering.

Бібл. 15, табл. 2, рис. 1 .

Ключові слова: моніторинг технічного стану, технічне діагностування, неруйнівний контроль, моніторинг теплоенергетичних установок, пасивні системи діагностики.

\section{Bcmyn}

При експлуатації теплоенергетичних установок і систем повинно бути забезпечено надійність, довговічність і безпека як системи в цілому, так і устаткування, що входить у систему $[1,2]$. Експлуатаційна надійність будь-якого обладнання полягає в його властивості виконувати задані функції, зберігаючи в часі значення встановлених технічною документацією експлуатаційних показників у допустимих межах, відповідних до заданих режимів і умов експлуатації. Експлуатаційна надійність визначається реальними умовами використання установок 3 урахуванням впливу всіх факторів, які залежать від якості проектування, виготовлення та експлуатації.

Забезпечення експлуатаційної надійності, довговічності i безпеки теплоенергетичного устаткування - складне завдання, яке пов'язане 3 організацією достовірного контролю роботи енергоустановок i з забезпеченням оптимальних умов їх експлуатації. Для розв'язання цього завдання необхідна наявність спеціальних систем моніторингу, що дозволяють неперервно контролювати технологічні процеси вироблення, транспортування та споживання теплоти; вимірювати основні параметри теплотехнічних установок, обладнання, машин, механізмів та ін.; діагностувати та прогнозувати технічний стан установок та їх вузлів.

Проблеми моніторингу різноманітних технічних об'єктів розглядаються в багатьох наукових працях [3 - 11], але практично відсутні роботи, в яких висвітлюються загальні принципи побудови систем моніторингу в теплоенергетиці.

Мета даної роботи полягає в формулюванні базових принципів моніторингу об'єктів теплоенергетики, систематизації основних видів та завдань систем моніторингу теплоенергетичного устаткування, характеристиці основних блоків апаратно-програмних засобів систем моніторингу, визначенні перспективних напрямів створення систем моніторингу в теплоенергетиці.

\section{Основні принципи моніторингу}

Моніторинг у загальному випадку - це процес досліджень різних об'єктів у часі і просторі, ïх взаємодії з оточуючим довкіллям при виконанні об’єктами заданих функцій для отримання поточних i прогнозованих характеристик, 
параметрів їх стану за даними спостережень, вимірювань, контролю, діагностики з метою подальшого використання цих характеристик для підвищення ефективності та безпеки роботи об'єктів [11]. Процес моніторингу забезпечує постійне оперативне отримання достовірної інформації про функціонування об'єктів теплоенергетики. Слід розрізняти моніторинг параметрів та моніторинг технічного стану об'єктів.

Моніторинг параметрів - це процес спостережень та вимірювань будь-яких поточних параметрів, зокрема параметрів, що характеризують технологічні процеси вироблення, транспортування та споживання теплоти; основних параметрів теплотехнічних установок, обладнання, машин та ін.

Результатом моніторингу параметрів $\epsilon$ сукупність виміряних значень параметрів, які в подальшому використовуються для контролю функціонування та ефективності роботи об'єктів та їх складових; управління технологічними процесами вироблення, транспортування та споживання теплоти; визначення технічного стану об'єкту та ін.

Моніторинг технічного стану об'єкту - це комплексна система спостереження, діагностування та прогнозу технічного стану об'єктів. Моніторинг технічного стану об'єкту принципово відрізняється від моніторингу параметрів наявністю інтерпретатора виміряних параметрів в термінах технічного стану - експертної системи для прийняття рішення про стан об’єкту та прогнозування стану.

Результатом моніторингу технічного стану об'єкту є діагноз об'єкту в цілому та сукупність діагнозів складових його частин (установок, вузлів, елементів, машин, механізмів тощо) i прогнозування часу зміни стану об'єкту та (або) його складових частин.

Технічний стан об'єкта характеризується у визначений момент часу і за визначених умов зовнішнього середовища значеннями параметрів, встановлених технічною документацією на об'єкт. Технічний стан складного об'єкта визначається технічним станом його складових частин - вузлів, механізмів, машин або конструкцій. Розрізняють наступні види технічного стану об'єкта (ГОСТ 27.00289) - справний, працездатний, правильного функціонування, граничний, неправильного функціонування, непрацездатний, несправний.

Порушення справності, працездатності або правильності функціонування об'єкта є наслідком появи в об'єкті або в його складових частинах дефектів, пошкоджень або відмов. Дефект - кожна окрема невідповідність властивостей об'єкта заданим, необхідним або очікуваним його властивостям. Пошкодження - подія, що полягає в порушенні справного стану об'єкта при збереженні працездатного стану. Відмова - подія, що полягає в порушенні працездатного стану об' єкта.

Дефекти, пошкодження та відмови $є$ наслідком конструктивних, виробничих, експлуатаційних і деградаційних причин [1 - 3]. Експлуатаційні причини пов'язані 3 порушенням установлених правил і (або) умов експлуатації. Деградаційні причини обумовлені природними процесами старіння, зношування, корозії та втоми при дотриманні всіх установлених правил i норм проектування, виготовлення та експлуатації.

Технічний стан кожного об'єкта характеризують різні фізичні величини - механічні, гідромеханічні, аеромеханічні, термодинамічні, електричні, електромагнітні, оптичні, акустичні та ін., 3 яких обирають множину діагностичних параметрів [12]. Значення діагностичних параметрів дозволяють визначити технічний стан та зміну технічного стану об'єкта без його розбирання. Основними критеріями при виборі тих чи інших фізичних величин як діагностичних параметрів $є$ використання тих фізичних полів і явищ, які максимально реагують на зміну стану матеріалу, умов навантаження, експлуатації та ін.; максимальна зміна значень фізичного параметра при зміні технічного стану об'єкта; можливість визначення фізичних параметрів без руйнування зразків.

Інформативність ознак, сформованих на обраних діагностичних параметрах, визначає склад вимірюваних фізичних величин, які використовуються надалі для визначення технічного стану об'єктів. Вимірювання обраних параметрів, як діагностичних фізичних величин, 
$€$ основою різних методів і засобів технічного діагностування.

Технічне діагностування - це визначення технічного стану будь-якого об'єкта (ДСТУ 2389-94). Діагностування здійснюється засобами діагностування, які являють собою відповідну апаратуру i програми. Система діагностування - це сукупність засобів діагностування, об’єкта і виконавців, необхідна для проведення діагностування за правилами, встановленими у технічній документації.

Завданнями технічного діагностування $\epsilon$ контроль функціонування або технічного стану; пошук місця і визначення причин відмови (несправності); прогнозування технічного стану. Контроль функиіонування полягає в перевірці виконання об'єктом частини або всіх властивих йому функцій. Контроль технічного стану полягає в перевірці відповідності значень параметрів об'єкта вимогам технічної документації і визначенні на цій основі одного iз заданих видів технічного стану в цей момент часу. Прогнозування технічного стану - визначення технічного стану об'єкта із заданою ймовірністю на майбутній інтервал часу.

Основними показниками якості систем діагностування є повнота діагностування, достовірність діагнозу і глибина пошуку місця відмови (несправності).

Розрізняють системи тестового $i$ функиіонального діагностування. У системах тестового діагностування на об'єкт подаються спеціально організовані тестові впливи, а системи функціонального діагностування працюють у процесі застосування об'єкта за призначенням і на об'єкт подаються тільки робочі впливи, передбачені алгоритмом його функціонування.

Технічне діагностування об’єктів теплоенергетики здійснюється методами неруйнівного контролю [12], після застосування яких об'єкти можна i надалі використовувати за їх прямим призначенням. Клас фізичних методів неруйнівного контролю (ДСТУ 2865-94) грунтується на дії фізичних полів або речовин на об'єкт, а також на реєстрації полів, що створюються самим об'єктом контролю.

Неруйнівний контроль в залежності від фізичних явищ, що покладені в його основу, поділяється на види (табл. 1), кожен 3 яких може бути використаний для моніторингу об'єктів теплоенергетики [12]. В рамках кожного виду неруйнівного контролю існує велике число різних методів, які класифікуються за наступними ознаками - характером взаємодії фізичних полів або речовин 3 об'єктом контролю; первинним інформативним параметром; способом отримання первинної інформації.

\section{Види та склад систем моніторингу тепло- енергетичного обладнання}

Процеси моніторингу реалізуються системами моніторингу, що включають об'єкт моніторингу, апаратно-програмні засоби та виконавців. Системи моніторингу повинні забезпечувати одержання інформації про виконання об'єктом всіх або частини властивих йому функцій; технічний стан устаткування i його небезпечність 3 необхідними коментарями (місце та можливі причини відмови або несправності; прогноз технічного стану та залишкового ресурсу; вказівки та розпорядження персоналу на невідкладні дії та ін.). За результатами спостереження системи моніторингу повинні завчасно виробляти керуючі впливи, які забезпечують необхідний запас стійкості технологічної системи, якість її функціонування, створюють необхідний запас іiі техногенної, екологічної та економічної безпеки. Узагальнена класифікація систем моніторингу в теплоенергетиці наведена на рис. 1.

Основним об'єктом моніторингу джерел генерації теплової енергії $є$ котельна установка в цілому та елементи іiі основного та допоміжного устаткування - топка, кип'ятильні та екранні труби, пароперегрівники, економайзери, парові, живильні та допоміжні трубопроводи, арматури трубопроводів, газоходи, вентилятори, димососи.

В найпростішому випадку системи моніторингу можуть бути спеціалізованими системами, що використовують лише один iз видів неруйнівного контролю. Перспективними в теплоенергетиці є комплексні системи, що здійснюють моніторинг на базі різних видів неруйнівного контролю. 
Системи індикаџіï стану здійснюють тільки визначення технічного стану об'єкту (справний - несправний), без вказівок на вид несправності. Діагностичні системи разом 3 визначенням технічного стану повинні визначати одну або декілька причин несправного стану об'єкту. Системи підтримки ухвалення рішень включають властивості діагностичних систем i додатково повинні видавати необхідні вказівки та розпорядження персоналу для запобігання небезпечному стану об'єкту і приведення його в нормальний стан. Ухвалення діагностичних рішень може здійснювати оператор, що використовує експертні підсистеми, або підсистема штучного інтелекту, що виконує функції експерта.

Системи з ручним управлінням виконують більшість функцій моніторингу під управлінням людини-оператора. Автоматизовані системи повинні виконувати основні функції моніторингу автоматично, а допоміжні - під управлінням людини-оператора. Автоматичні системи моніторингу повинні виконувати всі функції моніторингу автоматично. Людина в автоматичних системах може використовуватися як ланка управління для видачі управляючих дій на об'єкт.

Таблиця 1. Види та об’ єкти неруйнівного контролю

\begin{tabular}{|c|c|}
\hline Види контролю & Об’єкти контролю \\
\hline Магнітний & $\begin{array}{l}\text { Вироби } 3 \text { феромагнітних матеріалів. Дозволяє знаходити макродефекти - } \\
\text { гартівні i втомні тріщини, раковини, непровари, розшарування розміром } \\
\text { більше } 0,1 \text { мм на глибині до } 10 \text { мм }\end{array}$ \\
\hline Електричний & $\begin{array}{l}\text { У виробах з електропровідних матеріалів дозволяє знаходити тріщини на } \\
\text { глибині } 0,5 \ldots 100 \text { мм; застосовується також для контролю якості неелектроп- } \\
\text { ровідних захисних покриттів виробів з металу }\end{array}$ \\
\hline Вихретоковий & $\begin{array}{l}\text { Вироби з електропровідних матеріалів. Дозволяє знаходити в металевих ви- } \\
\text { робах поверхневі дефекти - тріщини, раковини, волосовини глибиною біль- } \\
\text { ше } 0,1 \text { мм, і грубі підповерхневі дефекти, розташовані на глибині до } 10 \text { мм }\end{array}$ \\
\hline Радіохвильовий & $\begin{array}{l}\text { Вироби з матеріалів, в яких радіохвилі не сильно згасають. Застосовується } \\
\text { для виявлення дефектів в різних неметалевих матеріалах, а також поверхне- } \\
\text { вих дефектів металів }\end{array}$ \\
\hline Тепловий & $\begin{array}{l}\text { Вироби з теплопровідних матеріалів. Застосовується для контролю теп- } \\
\text { лових навантажень поверхонь нагріву, теплових втрат в захисних } \\
\text { конструкціях і трубопроводах теплових мереж, дозволяє } \\
\text { металах поверхневі і підповерхневі дефекти }\end{array}$ \\
\hline Оптичний & $\begin{array}{l}\text { Вироби з матеріалів, прозорих для оптичного діапазону хвиль. Застосову- } \\
\text { ються для виявлення в важкодоступних місцях поверхневих дефектів розмі- } \\
\text { ром більше } 0,01 \text { мм, слідів течі і ін. }\end{array}$ \\
\hline Радіаційний & $\begin{array}{l}\text { Вироби з різних матеріалів. Дозволяє виявляти різноманітні дефекти - } \\
\text { раковини, непровари, розшарування та ін. Застосовується для контролю } \\
\text { якості зварки }\end{array}$ \\
\hline Акустичний & $\begin{array}{l}\text { Вироби } 3 \text { металів і діелектриків. Застосовується для контролю якості } \\
\text { зварки, корпусів, судин тиску, великих литих деталей, товстостінних } \\
\text { заготівок, вібраційного стану об'єктів і ін. }\end{array}$ \\
\hline \multirow[b]{2}{*}{$\begin{array}{l}\text { Проникними } \\
\text { речовинами }\end{array}$} & Методи течошукання - тільки для виявлення наскрізних дефектів \\
\hline & 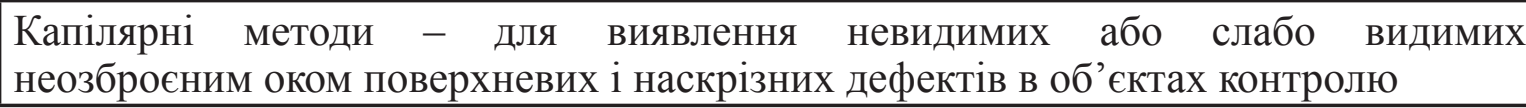 \\
\hline
\end{tabular}




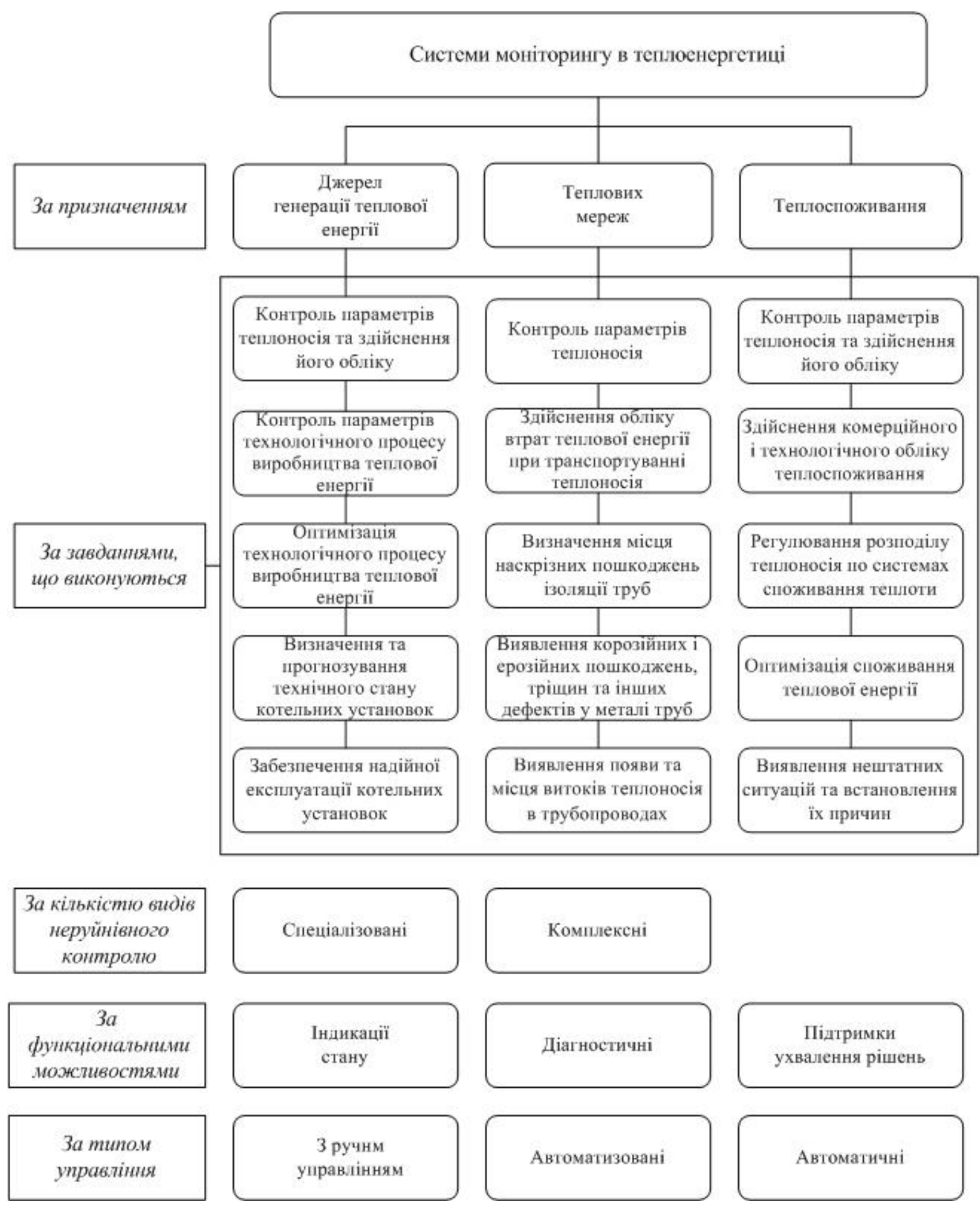

Рис. 1. Узагальнена класифікація систем моніторингу в теплоенергетиці. 
При побудові систем моніторингу теплоенергетичного устаткування в першу чергу необхідно визначити:

- об'єкт моніторингу та відповідне призначення системи;

- загальні параметри моніторингу об'єкту та його складових - виробничі параметри, параметри технологічних процесів, режимні параметри вузлів і елементів та ін.;

- д діагностичні сигнали;

- діагностичні параметри і характеристики;

- види і методи технічного діагностування;

- вимоги до функціональних можливостей системи та типу управління нею.

Сучасні системи моніторингу теплоенергетичного обладнання повинні здійснювати моніторинг в автоматичному або автоматизованому режимі та у реальному часі.

Апаратно-програмні засоби системи моніторингу можуть мати різноманітні структури i в загальному випадку складаються 3 таких основних блоків - збору та реєстрації діагностичних сигналів; формування діагностичних характеристик та параметрів; інформаційної бази даних i знань; прийняття рішень; реєстрації, відображення і сповіщення персоналу; управління і синхронізації; інтерфейсів.

Блок збору та реєстрації діагностичних сигналів формує масиви вихідних даних для моніторингу i включає датчики, попередні підсилювачі, аналогово-цифровий перетворювач та цифровий накопичувач. Зазвичай системи моніторингу в теплоенергетиці $\epsilon$ багатоканальними.

Блок формування діагностичних характеристик та параметрів на основі методів та алгоритмів цифрової обробки сигналів здійснює перетворення масиву вихідних даних в масив діагностичних параметрів, пов'язаних із станом об'єктів моніторингу.

Інформаційні бази даних $i$ знань забезпечують процес моніторингу необхідною інформацією. База даних включає конфігурацію устаткування, що діагностується, конфігурацію системи моніторингу, бази апріорних даних значень діагностичних характеристик i параметрів та їх межі, що визначають пев- ний технічний стан того чи іншого об'єкту моніторингу.

База знань зберігає за певний період реалізації зареєстрованих діагностичних сигналів, результати вимірювань діагностичних характеристик, параметрів, графіки зміни значень параметрів в часі (тренди); результати визначення технічного стану як установки в цілому, так $\mathrm{i}$ iii вузлів та елементів; журнали, протоколи подій, ремонтів та інші необхідні для роботи системи дані.

Блок прийняття рішень є експертною системою, яка на підставі вихідного масиву діагностичних параметрів і експлуатаційних даних, що зберігаються в інформаційній базі даних i знань, визначає стан об'єктів і видає необхідну діагностичну інформацію та (або) вказівки персоналу по приведенню об'єкту в допустимий стан. Експертна система повинна автоматично визначати і прогнозувати несправність контрольованого устаткування і видавати вказівки та рекомендації персоналу по подальших його діях.

Блок реєстрації, відображення і сповіщення персоналу доводить необхідну інформацію про стан устаткування до персоналу з використанням візуальних і звукових пристроїв та здійснює друкування протоколів на паперовому носії. Блок відображає дату і час включення (відключення) агрегату, веде підрахунок загального, місячного напрацювання, напрацювання між поточними, середніми і капітальними ремонтами та інше.

Блок управління $i$ синхронізації здійснює загальне управління роботою всією системою моніторингу за певними алгоритмами та (або) наборами адаптивних алгоритмів. Прив'язка апаратних i програмних засобів системи моніторингу до конкретного устаткування здійснюється шляхом конфігурації устаткування, що діагностується, та конфігурації системи моніторингу. Синхронізація здійснюється прив'язкою всіх блоків системи до реальної дати і часу. Блок управління може забезпечувати блокування аварійних агрегатів по комплексу параметрів, як безумовне, так i за наслідками діалогу з оператором.

Блок інтерфейсів здійснюе обмін інформацією між блоками системи та забезпечує 
зв'язок з користувачами. За допомогою мережних інтерфейсів інформація про результати моніторингу та стан устаткування передається зовнішнім зацікавленим службам по стандартних каналах зв'язку.

\section{Перспективні напрями створення систем моніторингу в теплоенергетиці}

На даний час центральну роль при вирішенні завдань моніторингу об'єктів теплоенергетики відіграють методи та засоби теплометрії, що базуються на безпосередньому вимірюванні температури та теплових потоків. Теплометричні прилади та системи [13] дозволяють здійснювати моніторинг ефективного та надійного виробництва теплоти та іiі транспортування, зокрема, контролювати якість палива та параметри процесу його спалювання, теплові навантаження радіаційних поверхонь нагріву i топічних екранів, визначати витоки теплоти через теплоізоляційні огороджуючи конструкції вузлів теплогенеруючих установок та трубопроводів теплових мереж.

В останні десятиріччя для контролю i діагностування теплоенергетичного устаткування в процесі їх експлуатації важливу роль відіграють пасивні системи функціональної діагностики, джерелом інформації в яких $\epsilon$ шумові та ритмічні сигнали (табл. 2), що виникають у результаті природного функціонування об'єктів [11].

Таблиця 2. Джерела і види шумових та ритмічних сигналів

\begin{tabular}{|c|c|}
\hline Джерела сигналів & Види сигналів \\
\hline $\begin{array}{l}\text { • Котли } \\
\text { • Газові турбіни } \\
\text { • Парові турбіни } \\
\text { • Газопоршневі двигуни } \\
\text { • Електричні генератори } \\
\text { • Електричні двигуни } \\
\text { - Трубопроводи котельних } \\
\text { установок } \\
\text { • Насоси, компресори } \\
\text { - Вентилятори } \\
\text { - Врубопроводи тепломереж } \\
\text { Високовольтне устаткування }\end{array}$ & $\begin{array}{l}\text { - Флуктуації температури } \\
\text { - Аеродинамічні шуми та вібрації турбін, компресорів, } \\
\text { електричних машин } \\
\text { • Гідродинамічні шуми та вібрації в насосах, трубопроводах } \\
\text { • Сигнали акустичної емісії } \\
\text { - Акустичні сигнали витоку } \\
\text { • Шуми тертя-ковзання } \\
\text { • Контактні шуми в колекторно-щіткових вузлах електрич- } \\
\text { них машин } \\
\text { • Магнітні шуми електричних машин } \\
\text { • Магнітні шуми Баркгаузена при перемагнічуванні } \\
\text { • Магнітострикційні шуми в трансформаторах } \\
\text { - Часткові розряди у високовольтному устаткуванні }\end{array}$ \\
\hline
\end{tabular}

Шумові сигнали є наслідком механічних, аеродинамічних, гідродинамічних і трибомеханічних процесів, що супроводжують роботу вузлів теплоенергетичного обладнання, i проявляються у вигляді акустичного, магнітного, електричного, теплового шуму або широкосмугових вібрацій.

Ритмічні сигнали є результатом взаємодії деталей у кінематичних парах газових турбін, газопоршневих двигунів, електричних машин, компресорів та ін., і проявляються, як правило, у вигляді вузькосмугових багаточастотних вібрацій.

Пасивні системи діагностики, що базують- ся на застосуванні шумових та ритмічних сигналів, широко використовуються для контролю та визначення технічного стану об'єктів теплоенергетики [14, 15]. Найбільш розповсюдженими системами діагностування теплоенергетичного обладнання, що використовують шумові сигнали, є акустико-емісійні системи та системи акустичного контактного течошукання, а ритмічні сигнали - віброакустичні системи [11].

Сучасні акустико-емісійні системи забезпечують реєстрацію сигналів акустичної емісії та вимірювання як окремих параметрів сигналів акустичної емісії, так і їх імовірнісних характеристик - щільності ймовірностей миттєвих 
значень, кореляційно-спектральних характеристик. Акустико-емісійні системи дозволяють здійснювати контроль стану металоконструкцій елементів теплоенергетичного обладнання та виявляти появу, розвиток і координати дефектів в елементах теплоенергетичних установок.

Більшість приладів і систем акустичного контактного течошукання витоків рідини в трубопроводах котельних установок та теплових мереж базуються на кореляційній і спектральній обробці акустичних сигналів витоку та дозволяють виявляти появу течі і визначати іiі координати.

Сучасні прилади і системи вібродіагностики базуються на імовірнісному аналізі віброакустичних сигналів, зокрема, на аналізі форми сигналу, щільності ймовірностей його миттєвих значень, спектральному, кореляційному, кепстральному аналізі, вейвлет-аналізі та ін. Найпоширенішим $є$ спектральний аналіз вібрацій, який дозволяє виявляти різноманітні дефекти в елементах тепломеханічного обладнання - дисбаланс ротора, робочого колеса; неспіввісність валів; нежорстке кріплення; дефекти електродвигунів, компресорів, насосів, вентиляторів, приводних муфт, зубчастих i пасових передач, підшипників кочення та ковзання.

Слід зазначити, що статистичний аналіз діагностичних сигналів в більшості сучасних пасивних систем функціональної діагностики базується на кореляційно-спектральних методах, які є вичерпними для гауссівських сигналів. Однак аналіз результатів теоретичних і експериментальних досліджень показав [11], що шумові та ритмічні сигнали, як правило, $\epsilon$ негауссівськими випадковими процесами i часто мають рівномірну спектральну щільність. Це обмежує можливості існуючих пасивних систем діагностики, заснованих на методах кореляційного і спектрального аналізу.

Таким чином, один з основних перспективних напрямів подальшого розвитку методів i засобів моніторингу об'єктів теплоенергетики полягає у вдосконалені існуючих та розробці нових пасивних систем діагностики, які базуються на сучасних методах теорії випадкових процесів і статистичної обробки шумових та ритмічних сигналів.

Створення нових пасивних систем діагностики для визначення технічного стану елементів теплоенергетичного обладнання, підвищення їх чутливості та достовірності потребує вирішення таких основних завдань:

- побудові адекватних математичних моделей шумових та ритмічних сигналів, що супроводжують роботу елементів теплоенергетичного обладнання та відображають фізику їх виникнення;

- визначенні найбільш інформативних характеристик та параметрів, які дозволяють контролювати та діагностувати технічний стан елементів теплоенергетичного обладнання;

- розробці статистичних методів та програмного забезпечення для експериментального визначення нових інформативних характеристик та параметрів.

Систематизація основних математичних моделей шумових та ритмічних сигналів [11] показала, що найбільш універсальною та добре вивченою моделлю таких сигналів, що відображає фізику їх виникнення, в даний час є лінійні випадкові процеси. В результаті дослідження та аналізу імовірнісних характеристик лінійних випадкових процесів встановлена доцільність та перспективність використання як діагностичних характеристик моментних i кумулянтних функцій вищих порядків та законів розподілу інформаційних сигналів.

Для знаходження функції розподілу негауссівських інформаційних сигналів в загальному випадку необхідно використання наближених методів. Широкі можливості для аналізу законів розподілів негауссівських сигналів має застосування методів апроксимації щільності ймовірностей сумішами розподілів та рядами 3 ортогональними поліномами, які в даний час використовуються мало. Перспективними діагностичними характеристиками $\epsilon$ пуассонівські спектральні функції, які дозволяють знаходити закони розподілу, як шумових сигналів, так і їх лінійних перетворень. 


\section{Висновки}

Системи моніторингу дозволяють отримувати достовірну інформацію про функціонування об’єктів теплоенергетики. Зокрема, моніторинг параметрів забезпечує неперервний контроль основних параметрів теплотехнічних установок і технологічних процесів вироблення, транспортування та споживання теплоти. В результаті моніторингу технічного стану теплоенергетичного об'єкту встановлюється діагноз об'єкту та прогнозування часу зміни його стану.

Моніторинг теплоенергетичного обладнання повинен здійснюватися на базі різних видів неруйнівного контролю у реальному часі в автоматичному або автоматизованому режимі. Один iз перспективних напрямів подальшого розвитку методів і засобів моніторингу об'єктів теплоенергетики полягає у вдосконалені існуючих та розробці нових пасивних систем діагностики, в яких джерелом інформації $\epsilon$ шумові та ритмічні сигнали, що виникають у результаті природного функціонування об'єктів. Використання як моделі таких сигналів лінійних випадкових процесів, а як діагностичних параметрів - їx моментних i кумулянтних функцій вищих порядків та законів розподілу, може розширити можливості пасивних систем діагностики і перспективи їх подальшого впровадження.

\section{ЛІТЕРАТУРА}

1. Надежность теплоэнергетического оборудования ТЭС и АЭС: Учеб. пособие для вузов / Г.П. Гладышев и др.; Под ред. А.И. Андрющенко. - М.: Высш. шк., 1991. $\neg 301$ с.

2. Беляев С.А., Литвак В.В., Солод С.С. Надежность теплоэнергетического оборудования ТЭС. - Томск: Изд-во НТЛ, 2008. - 218 с.

3. Мадоян А.А., Канцедалов В.Г. Дистанционный контроль оборудования ТЭС и АЭС. - М.: Энергоатомиздат, 1985. - 200 с.

4. Герике Б.Л. Мониторинг и диагностика технического состояния машинных агрегатов: Учеб. пособие. - В 2-х ч. - Ч.1. Мониторинг технического состояния по параметрам вибрационных процессов. - Кемерово: Кузбасс. техн. ун-т, 1999. $-188 \mathrm{c}$.
5. Поливанов В.И., Рыков В.А., Злепко В.Ф. и др. Мониторинг длительной прочности котельных труб работающего энергооборудования // Электрические станции. - 2001. - № 1. - С. 5-12.

6. Смирнов А.Н., Герике Б.Л., Муравьев В.В. Диагностирование технических устройств опасных производственных объектов. - Новосибирск: Наука, 2003. - 244 с.

7. Бабенко В. Р., Кузнецов Р.С., Орлов С.И. и др. Система мониторинга и анализа режимов функционирования потребителей тепловой энергии // Информатизация и системы управления в промышленности. - 2005. - № 7. - С. 23-28.

8. Недосека А.Я., Недосека С.А., Яременко М.A. и др. Применение АЭ технологии при непрерывном мониторинге оборудования Одесского припортового завода // Техническая диагностика и неразрушающий контроль. - 2008.№ 4. - C. 85-95.

9. Хейфеи А.И. Внедрение системы мониторинга состояния технологического оборудования тепловых сетей, опыт и перспектива использования // Энергосовет. - 2010. - №7(12). - С. 16-21.

10.Стогній Б.С., Сопель М.Ф. Основи моніторингу в електроенергетиці. Про поняття моніторингу // Технічна електродинаміка. - 2013. - № 1. - С. 62-69.

11.Інформаційне забезпечення моніторингу об'єктів теплоенергетики / В.П. Бабак, С.В. Бабак, В.С. Берегун та ін.; за ред. В.П. Бабака. - К.: Ін-т технічної теплофізики НАН України, 2015. $512 \mathrm{c}$.

12.Неразрушаюший контроль и диагностика: Справочник / В.В. Клюев, Ф.Р. Соснин, А.В. Ковалев и др.; Под ред. В.В. Клюева. - 2-е изд., испр. и доп. - М.: Машиностроение, 2003. - 656 c.

13.Грищенко Т.Г., Декуша Л.В., Воробйов Л.Й. Засоби вимірювальної техніки для діагностики, моніторингу та оптимізації режимів роботи об'єктів у комунальній теплоенергетиці та будівельній індустрії / В кн. «Комунальна теплоенергетика України: стан, проблеми, шляхи модернізації». - Т. 1. - К.: Ін-т технічної теплофізики НАН України, 2007. - С. 346-386. 
14.Акустическая диагностика и контроль на предприятиях топливно-энергетического комплекса / В.М. Баранов, А.И. Гриценко, А.М. Карасевич и др. - М.: Наука, 1998. - 304 с.

15.Неразрушающий контроль: Справочник:

\section{PRINCIPLES OF CONSTRUCTION OF THE MONITORING SYSTEMS IN HEAT-POWER ENGINEERING}

\section{Babak V.P., Krasil'nikov A.I.}

Institute of Engineering Thermophysics of the National Academy of Sciences of Ukraine, vul. Zheliabova, 2a, Kyiv, 03680, Ukraine

The work's purpose is the formulation of the base principles of monitoring of the heat-power engineering objects; the systematization of the main types and tasks of monitoring systems of heatpower equipment; the definition of the perspective directions of monitoring systems creating in heatpower engineering. Monitoring of the heat power equipment should be carried out on the basis of various kinds of non-destructive testing in real-time in automatic or automatized modes. Perspective are the systems for monitoring of heat-power engineering objects, in which noise signals and rhythmic signals, resulting from the natural functioning of the objects, are the source of information. Using the linear random processes as the model of such signals and their cumulant functions and distribution laws in the capacity of the diagnostic parameters can extend the ability of monitoring systems.

References 15, tables 2, figures 1 .

Key words: monitoring of technical state, technical diagnostics, non-destructive control, monitoring of
В 8 т. / Под общ. ред. В.В. Клюева. Т. 7: В 2 кн. Кн. 1: В.И. Иванов, И.Э. Власов. Метод акустической эмиссии. Кн. 2: Ф.Я. Балицкий, А.В. Барков, Н.А. Баркова и др. Вибродиагностика. - 2-е изд., испр. - М.: Машиностроение, 2006. - 829 с.

heat-and-power plants, passive diagnostics systems.

1. Reliability of heat-and-power equipment of thermal power stations and nuclear power stations: Train aid for institutions of higher learning / G.P. Gladyshev i dr.; Pod red. A.I. Andryushchenko. Moscow: Vysshaya shkola, 1991. - 301 p. (Rus.)

2. BelyaevS.A., Litvak V.V., Solod S.S. Reliability of heat-and-power equipment of thermal power stations. - Tomsk: Izdatelstvo NTL, 2008. - 218 p. (Rus.)

3. Madoyan A.A., Kantsedalov V.G. Distance control of equipment of thermal power stations and nuclear power stations. - Moscow: Energoatomizdat, 1985. - 200 p. (Rus.)

4. Gerike B.L. Monitoring and diagnostics of the technical state of machine aggregates: Train aid. - In 2 parts. - P. 1 Monitoring of the technical state on the parameters of vibration processes. Kemerovo: Kuzbasskiy tekhnicheskiy universitet, 1999. - 188 p. (Rus.)

5. Polivanov V.I., Rykov V.A., Zlepko V.F. i dr. Monitoring of the protracted durability of caldron pipes of working energy equipment // Elektricheskie stantsii. - 2001. - № 1. - P. 5-12. (Rus.)

6. Smirnov A.N., Gerike B.L., Muravyov V.V. Diagnosticating of technical devices of dangerous productive objects. - Novosibirsk: Nauka, 2003. 244 p. (Rus.)

7. Babenko V.R., Kuznetsov R.S., Orlov S.I. i dr. Monitoring and analysis system of the functioning modes of consumers of thermal energy // Informatizatsiya i sistemy upravleniya $\mathrm{V}$ 
promyshlennosti. - 2005. - № 7. - P. 23-28. (Rus.)

8. Nedoseka A.Ya., Nedoseka S.A., Yaremenko M.A. i dr. Application of acoustic emission technology at the continu-ous monitoring of equipment of the Odessa port plant // Tekhnicheskaya diagnostika i nerazrushayushchiy kontrol. - 2008. - № 4. P. 85-95. (Rus.)

9. Kheyfets A.I. Introduction of the monitoring system of the state of technological equipment of thermal networks, experience and prospect of the use // Energosovet. - 2010. - № 7 (12). - P. 16-21. (Rus.)

10. Stohnii B.S., Sopel M.F. Monitoring bases in an electric energy. About the concept of monitoring // Tekhnichna elektrodynamika. - 2013. - № 1. P. 62-69. (Ukr)

11. Information providing of monitoring of heat-and-power engineering objects / V.P. Babak, S.V. Babak, V.S. Berehun ta in.; za red. V.P. Babaka. - Kyiv: Instytut tekhnichnoi teplofizyky NAN Ukrainy, 2015. - 512 p. (Ukr)

12. Non-destructive control and diagnostics: Reference Book / V.V. Klyuev, F.R. Sosnin, A.V. Kovalyov i dr.; Pod red. V.V. Klyueva. - 2-e izd., ispr. i dop. - Moscow: Mashinostroenie, 2003. - 656 s. (Rus.)

13. Hryshchenko T.H., Dekusha L.V., Vorobiov L.I. Facilities of measuring technique for diagnostics, monitoring and optimization of the operations modes of objects in communal heatand-power engineering and building industry / In book "Communal heat-and-power engineering of Ukraine: the state, problems, ways of modernisation". - Vol. 1. - Kyiv: Instytut tekhnichnoi teplofizyky NAN Ukrainy, 2007. - P. 346-386. (Ukr)

14. Acoustic diagnostics and control on the enterprises of fuel and energy complex / V.M. Baranov, A.I. Gritsenko, A.M. Karasevich i dr. Moscow: Nauka, 1998. - 304 p. (Rus.)

15. Non-destructive control: Reference Book: In 8 volumes / Pod obshch. red. V.V. Klyueva. Vol. 7: In 2 books. Book 1: V.I. Ivanov, I.E. Vlasov. Acoustic emission method. Book 2: F.Ya. Balitskiy, A.V. Barkov, N.A. Barkova i dr. Vibration diagnostics. 2-e izd., ispr. - Moscow: Mashinostroenie, 2006. 829 p. (Rus.)

Получено 02.11.2015 Received 02.11.2015 